\title{
Isozyme polymorphism in a collection of Spanish and French perennial ryegrass populations
}

\author{
JA Oliveira', F Balfourier ${ }^{2 *}, \mathrm{G} \mathrm{Charmet}^{2}$, E Arbones ${ }^{1}$ \\ ' Centro de Investigaciones Agrarias de Mabegondo, Apartado 10. 15080 La Coruña, Spain; \\ ${ }^{2}$ Station d'amélioration des plantes, Institut national de la recherche agronomique, 63039 Clermont-Ferrand, France
}

(Received 5 february 1997; accepted 14 october 1997)

\begin{abstract}
Summary - Twenty-eight natural populations of perennial ryegrass (Lolium perenne $L$ ) collected from a latitudinal and a longitudinal gradient in Spain, Portugal and France were screened for allozyme diversity at ten loci. Population genetic statistics were found to be of the same magnitude as those previously reported for other outbreeding species (average number of alleles per locus $=2.82$, observed heterozygosity $=0.289$ and expected heterozygosity $=0.312$ ). Genotype frequencies at most collection sites did not deviate significantly from Hardy-Weinberg expectations. Gene diversity was mainly explained by the within population component. The between population differentiation $\left(\mathrm{F}_{\mathrm{ST}}\right)$ averaged over seven loci was 0.073 , which only accounted for $7.9 \%$ of the whole diversity. Non-metric multidimentional scaling carried out on the matrix of Cavalli chord distances, based on allelic frequencies, showed that the global differentiation between the populations was partly explained by the latitude and the altitude of the collection sites. Thus, a south-north cline was observed for ACP2-20 and PGI2-20 alleles. In the same way, more SDK1-30 and PGI2-20 alleles were found in populations from higher altitudes. Hypotheses on the origin of such clinal trends are briefly discussed.
\end{abstract}

allozymes / genetic diversity / Lolium perenne L / natural populations

Résumé - Polymorphisme isoenzymatique au sein d'une collection franco-espagnole de populations naturelles de ray-grass anglais. Vingt-huit populations naturelles de ray-grass anglais collectées suivant un gradient longitudinal et latitudinal en Espagne, au Portugal et en France ont été évaluées pour la diversité isoenzymatique de dix loci. Les valeurs des statistiques de diversité génétique apparaissent du même ordre de grandeur que celles rapportées pour d'autres espèces allogames (nombre moyen d'allèles $=2,82$, hétérozygotie moyenne observée $=0,289$, hétérozygotie moyenne espérée $=0,312$ ). Les fréquences génotypiques dans la plupart des populations sont conformes à celles attendues sous équilibre panmictique. La diversité génétique est expliquée essentiellement par la composante intrapopulation, tandis que la diversité interpopulation ne représente que $7,9 \%$ de la diversité totale. Une analyse factorielle appliquée sur la matrice des distances de Cavalli obtenues à partir des fréquences alléliques a montré que la différenciation globale entre les populations était associée à la latitude et l'altitude des lieux de collecte. Ainsi, pour les allèles ACP2-20 et PGI2-20 une variation clinale sud/nord a été observée. De même, dans les populations provenant des lieux les plus élevées, les allèles SDK1-30 et PGI2-20 ont été trouvés en fréquences plus élevées. Des hypothèses sur l'origine possible de tels clines sont brièvement discutées.

allozymes / diversité génétique / Lolium perenne $\mathrm{L}$ / populations naturelles

Article communicated by Michael Hayward (Aberystwytr)

* Correspondence and reprints

Tel: (33) 04736243 46; fax: (33) 04736244 53; e-mail : balfour@valmont.clermont.inra.fr 


\section{INTRODUCTION}

Perennial ryegrass (Lolium perenne $L$ ) is the second most frequently sown fodder grass in Spain, after annual ryegrass ( $L$ multiflorum) with 2000 and 3000 tonnes of seed consumed per year, respectively (Piñeiro and Perez, 1992). The UE agricultural policy towards limitation of cereal production and encouragement of a non-agricultural use of land may further increase the interest for grass species such as Lolium, especially for use in unfavorable areas such as the north of Spain. Because perennial ryegrass is mainly cultivated in the oceanic regions of Europe, a sample of populations has been collected in 'natural' meadows (very old meadows with no record of recent sowing with important cultivars), following a latitudinal and a longitudinal gradient from the northwest oceanic coast of Spain to the north of France in order to obtain a diverse germplasm for plant breeding in southwestern Europe.

As genetic resources are primarily of use for plant breeders, who look for adaptive traits, an assessment of these genetic resources for their ability to have good seasonal growth was carried out and will be presented in another paper (Balfourier et al, 1997).

Survey of isozyme variation in natural populations of forage grasses have already been reported for ryegrass (Hayward, 1985; Arcioni et al, 1988; Oliveira and Charmet, 1988; Charmet et al, 1993; Balfourier and Charmet, 1994; Charmet and Balfourier, 1994; Loos, 1994). Variation at isozyme loci is generally considered as selectively neutral (Kimura, 1983). However, sometimes, allelic frequencies of isozyme are correlated with environmental factors, thus possibly reflecting selection pressures (Nevo et al, 1986).

The aims of this isozyme study were to investigate 1) the importance of genetic differentiation in relation to the geographic distance of populations (genetic markers supposed neutral) and 2) whether there were alleles showing latitudinal, altitudinal or longitudinal gradients that could be markers of adaptative traits.

\section{MATERIALS AND METHODS}

\section{Isozyme procedures}

Twenty-eight wild populations of perennial ryegrass were collected as seed from Spain, Portugal and France in 1990 . Out of these 28 populations, 16 were sampled from Spain (Nos 1-16), one from Portugal (No 17), and 11 from France (Nos 18-28).

Populations were sampled to represent latitudinal and longitudinal gradients, sites ranging from latitude 41.45 to $50.71^{\circ} \mathrm{N}$ and from longitude $9.10^{\circ} \mathrm{W}$ to $2.74^{\circ} \mathrm{E}$, and altitudes ranging from 10 to $1050 \mathrm{~m}$. Each population was collected as seed from at least 50 plants taken from an ecologically homogeneous area of $100-1000 \mathrm{~m}^{2}$. These conditions are thought to yield a sample of seeds representative of the original population (Tyler et al, 1984). Unlike in more northern countries, most plant are able to head in southern countries under moderate grazing. Therefore, collecting seeds does not bias the population of living plants too much.

From each of the 28 populations, approximately 100 plants were studied using isozyme electrophoresis techniques following Hayward and McAdam (1977), Ostergaard et al (1985), Pollans and Allard (1985) and Greneche et al (1991). Slices of two starch gels and two different buffer systems were used, which permitted the study of nine enzyme systems, giving ten readable loci. Histidine-citrate buffer was used for acid phosphatase (ACP, EC 3132 ), isocitrate dehydrogenase (IDH, EC 1111 42), malate dehydrogenase (MDH, EC 111137 ), phosphogluco-isomerase (PGI, EC 53 19), phosphogluco-mutase (PGM, EC 275 1), peroxidase (PRX, EC 111117 ) and shikimate dehydrogenase (SKD, EC 1111 25). Tris-citrate-lithiumborate buffer was used for glutamate oxaloacetatetransaminase (GOT, EC 2611 ) giving two readable loci, and superoxide-dismutase (SOD, EC 115151 ). Allele nomenclature and isozymes procedures were those of Hayward et al (1995).

\section{Statistical analysis}

Allelic frequencies were determined by direct allele counting. Standard stastistics for characterizing genetic variability were computed for all accessions using the BIOSYS 1 program (Swofford and Sealander, 1981). The following population genetic statistics were computed: mean number of alleles per locus (A), average observed heterozygosity $\left(\mathrm{H}_{\mathrm{O}}\right)$ and expected heterozygosity under panmixia $(\mathrm{H})$. Wright's $(1965)$ fixation indices were calculated: $F_{\text {IT }}$ represents the fixation of the individuals relative to whole population; $F_{I S}$ gives the fixation of individuals within populations. Both parameters measure the surplus or deficit of heterozygotes, and can become negative; $\mathrm{F}_{\mathrm{ST}}$ is the fixation index that represents the differentiation level of the populations, and is equivalent to Nei's (1977) $\mathrm{G}_{\mathrm{ST}}$ for biallelic loci. The distances between all populations, based on allelic frequencies, were calculated using the chord distance of Cavalli-Sforza and Edwards (1967). The populations were scaled in a two-dimensional space using non-metric scaling (Kruskal and Wish, 1978). This is a class of methods for estimating the coordinates of a set of objects in a space of specified dimensionality from data measuring the distances between a pair of objects. Regression analysis was used to investigate the relationship between the first 
two axes obtained by non-metric scaling and some explanatory variables (altitude, latitude and longitude of the collection site).

Logistic regression analysis is often used to investigate the relationship between binary and ordinal response variables and explanatory variables (Cox and Snell, 1989; Collett, 1991). In this study, logistic regression analysis was carried out between the allelic frequencies of the populations and the altitude, latitude and longitude. All these analyses were carried out using the ' $\mathrm{S}$ ' programing environment (Becker et al, 1988).

\section{RESULTS}

Population diversity indices are summarized in table I. Mean number of alleles per locus and average heterozygosities found in this sample of ryegrass populations are, respectively: $\mathrm{A}=2.82$, $\mathrm{H}_{\mathrm{O}}=0.289$ and $\mathrm{H}=0.312$. Table II shows the summary statistics of allelic frequencies in the populations studied. All the enzymatic systems are polymorphic. A total of 41 alleles has been found. The PGI2 locus contained the highest number of alleles, with up to eight alleles, while SOD1 and MDH1 loci contained the fewest, with only three alleles. Of 41 alleles, 21 ( $\$$ ) can be considered as common widespread according to the classification of Brown (1978), eight (*) as rare widespread (mean frequency less than $5 \%$, but present in more than half of the populations), and $12(* *)$ as rare and sporadic. Eight alleles of
Table I. Parameters of genetic variability at ten loci in 28 populations, including average number of alleles per locus $(A)$, observed heterozygosity $\left(\mathrm{H}_{\mathrm{O}}\right)$ and expected heterozygosity $(\mathrm{H})$.

\begin{tabular}{llclll}
\hline Pop & Origin & Location & $A$ & $H_{O}$ & $H$ \\
No & & & & & \\
\hline 1 & Spain & Galicia & 2.7 & 0.218 & 0.250 \\
2 & Spain & Galicia & 2.6 & 0.212 & 0.226 \\
3 & Spain & Galicia & 2.3 & 0.222 & 0.211 \\
4 & Spain & Galicia & 2.8 & 0.282 & 0.284 \\
5 & Spain & Galicia & 3.0 & 0.305 & 0.371 \\
6 & Spain & Galicia & 2.9 & 0.285 & 0.307 \\
7 & Spain & Galicia & 2.8 & 0.250 & 0.280 \\
8 & Spain & Asturias & 3.2 & 0.358 & 0.398 \\
9 & Spain & Asturias & 2.9 & 0.315 & 0.334 \\
10 & Spain & Asturias & 3.0 & 0.314 & 0.344 \\
11 & Spain & Asturias & 2.8 & 0.200 & 0.216 \\
12 & Spain & Asturias & 2.8 & 0.284 & 0.315 \\
13 & Spain & Asturias & 3.4 & 0.369 & 0.429 \\
14 & Spain & Cantabria & 2.4 & 0.258 & 0.286 \\
15 & Spain & Pais Vasco & 2.7 & 0.261 & 0.297 \\
16 & Spain & Pais Vasco & 3.4 & 0.328 & 0.378 \\
17 & Portugal & Vila Real & 2.9 & 0.327 & 0.317 \\
18 & France & Pyrénées Atlantiques & 2.9 & 0.275 & 0.302 \\
19 & France & Charente Maritime & 3.1 & 0.314 & 0.346 \\
20 & France & Charente & 2.3 & 0.253 & 0.266 \\
21 & France & Morbihan & 3.1 & 0,336 & 0.348 \\
22 & France & Manche & 2.9 & 0.327 & 0.319 \\
23 & France & Calvados & 3.1 & 0.314 & 0.322 \\
24 & France & Orne & 2.8 & 0.254 & 0.314 \\
25 & France & Seine Maritime & 2.6 & 0.334 & 0.320 \\
26 & France & Pas de Calais & 2.4 & 0.284 & 0.305 \\
27 & France & Somme & 2.7 & 0.323 & 0.324 \\
28 & France & Somme & 2.7 & 0.296 & 0.323 \\
mean & & & 2.82 & 0.289 & 0.312 \\
se & & & 0.38 & 0.069 & 0.071 \\
\hline \multicolumn{7}{c}{} & & & &
\end{tabular}

Table II. Average frequencies of alleles detected in the Spanish and French ryegrass populations.

\begin{tabular}{|c|c|c|c|c|c|c|c|}
\hline Allele & Mean freq & Min & $\operatorname{Max}$ & Allele & Mean freq & Min & $\operatorname{Max}$ \\
\hline PGI2-10 ** & 0.007 & 0 & 0.107 & SOD $1-10 * *$ & 0.004 & 0 & 0.069 \\
\hline PGI2-20 $\S$ & 0.300 & 0.083 & 0.540 & SOD $1-20 \S$ & 0.052 & 0 & 0.235 \\
\hline PGI2-28 ** & 0.001 & 0 & 0.013 & SOD $1-30 \S$ & 0.943 & 0.760 & 1 \\
\hline PGI2-30 $\S$ & 0.521 & 0.310 & 0.712 & PRX1-30§ & 0.053 & 0 & 0.255 \\
\hline PGI2-40 \& & 0.063 & 0.006 & 0.146 & PRX $1-40 \S$ & 0.947 & 0.745 & 1 \\
\hline PGI2-45 * & 0.046 & 0 & 0.118 & PRX $1-50 * *$ & $<0.001$ & 0 & 0.007 \\
\hline PRI2-50* & 0.048 & 0 & 0.320 & IDH $1-20 *$ & 0.019 & 0 & 0.113 \\
\hline PGI2-60 ** & 0.015 & 0 & 0.115 & IDH $1-30 \S$ & 0.492 & 0.085 & 0.887 \\
\hline ACP2-20§ & 0.369 & 0.007 & 0.770 & IDH1-40 $\S$ & 0.475 & 0.107 & 0.915 \\
\hline ACP2-30 \$ & 0.534 & 0.162 & 0.966 & IDH $1-50 *$ & 0.014 & 0 & 0.171 \\
\hline ACP2-40 $\$$ & 0.066 & 0 & 0.202 & SKD 1 $10 * *$ & $<0.001$ & 0 & 0.007 \\
\hline ACP $2-50 *$ & 0.031 & 0 & 0.164 & SKD1-20 * & 0.034 & 0 & 0.154 \\
\hline GOT2-10** & 0.011 & 0 & 0.160 & SKDI-30 § & 0.914 & 0.825 & 0.995 \\
\hline GOT2-20§ & 0.313 & 0.015 & 0.701 & SKD $1-40 \S$ & 0.051 & 0 & 0.140 \\
\hline GOT2-30 $\S$ & 0.668 & 0.269 & 0.985 & PGM1-10** & $<0.001$ & 0 & 0.015 \\
\hline GOT $2-40 * *$ & 0.008 & 0 & 0.152 & PGM $1-20 \S$ & 0.608 & 0.395 & 0.792 \\
\hline GOT3-20* & 0.024 & 0 & 0.192 & PGM1-30 § & 0.373 & 0.197 & 0.545 \\
\hline GOT3-30 $\S$ & 0.865 & 0.722 & 1 & PGM1-40** & 0.018 & 0 & 0.081 \\
\hline GOT3-40 \$ & 0.099 & 0 & 0.221 & MDH $1-10 * *$ & 0.001 & 0 & 0.110 \\
\hline \multirow[t]{2}{*}{ GOT3-50 ** } & 0.012 & 0 & 0.153 & MDH1-20 \& & 0.961 & 0.775 & 1 \\
\hline & & & & MDH1-30* & 0.032 & 0 & 0.210 \\
\hline
\end{tabular}

$\S=$ common allele; $*$ rare widespread allele; $* *=$ rare and sporadic allele. 
Table III. Wright's fixation indices.

\begin{tabular}{lrcc}
\hline Loci & $F_{I S}$ & $F_{I T}$ & $F_{S T}$ \\
\hline PGI2 & -0.018 & 0.033 & 0.050 \\
ACP2 & 0.105 & 0.198 & 0.104 \\
GOT2 & 0.187 & 0.268 & 0.100 \\
GOT3 & 0.099 & 0.164 & 0.071 \\
SOD1 & 0.118 & 0.187 & 0.078 \\
PRX1 & 0.280 & 0.328 & 0.066 \\
IDH1 & 0.020 & 0.141 & 0.124 \\
SKD1 & 0.041 & 0.076 & 0.036 \\
PGM1 & 0.023 & 0.062 & 0.040 \\
MDH1 & 0.005 & 0.092 & 0.087 \\
mean of seven loci & 0.039 & 0.109 & 0.073 \\
\hline
\end{tabular}

this last category reach a frequency of $5 \%$ or more in at least one population, while the others have a very low frequency of less than $2 \%$.

The values of Wrights' fixation indices for each locus averaged across all loci are given in table III. The fixation indices are lower for PGI2, ACP2, GOT3, IDH1, SKD1, PGM1 and MDH1 compared with the other loci, showing that populations are in panmictic equilibrium for these loci. PRX1, GOT2 and SOD1 loci show higher fixation indices $F_{\text {is }}$ and $F_{i t}$, which illustrate their deficits in heterozygotes. The discrepancy between these three loci and the other seven loci may be accounted for by some misinterpretation of gel patterns. Therefore we used only the seven loci PGI2, ACP2, GOT3, IDH1, SKD1, PGM1 and MDH1 in averaging $F$ statistics. The mean level of between population differentiation $\left(\mathrm{F}_{\mathrm{ST}}\right)$ is 0.073 . The among population differentiation can also be expressed as a proportion of the diversity index $\mathrm{H}$ (mean heterozygosity expected under panmixia) by $\mathrm{D}_{\mathrm{ST}} / \mathrm{H}=\mathrm{F}_{\mathrm{ST}} /\left(1-\mathrm{F}_{\mathrm{ST}}\right)(\mathrm{Nei}, 1977)$. In this study $\left(\mathrm{D}_{\mathrm{ST}} / \mathrm{H}=0.073 / 0.927=0.079\right)$ only $7.9 \%$ of the genetic diversity is accounted for by among population differentiation.

The results from non-metric multidimentional scaling of the distances between the populations are presented in figure 1 . The first two axes account for 23.1 and $19.4 \%$ of the total variance, respectively. This figure shows that the northern French populations are grouped at the bottom right corner of the figure, indicating that these populations have relatively short distances between them. With regards Spanish populations, most of them are scattered all over the plot except some northwest populations that are grouped together, such as Sp1, Sp2 and Sp3 and Sp4, Sp5 and Sp6.

Linear regression carried out on the first two axes of non-metric scaling showed that the second axis is significantly explained by latitude ( $r=$ $0.571, P<0.01$ ).

The logistic regression between allelic frequencies and altitude, latitude and longitude reveals several significant $(P<0.001)$ relationships. Results of deviances (Collett, 1991) are given in table IV for the most significant relationships. Two alleles show a trend toward a latitudinal clinal variation: ACP2-20 and PGI2-20 are more frequent in the north than in the south as presented in figure 2 for the PGI2-20 allele. On the other hand, in populations from higher altitudes, more SDK130 and PGI2-20 alleles were found; figure 3 illustrates the logistic regression between SDK 1-30 allele frequency and altitude of collection site.

\section{DISCUSSION}

As reported in other publications, native populations of perennial ryegrass collected in Spain and France showed a wide range of isozyme variation (Oliveira and Charmet, 1988).

The average genetic diversity indices A (2.82) and $\mathrm{H}(0.312)$ of this study are higher than those reported by Hamrick and Godt (1990) for outcrossing, wind pollinating species. Our diversity indices are very similar to those reported by Hayward (1985) in 40 natural populations from Britain ( $\mathrm{A}=3.09, \mathrm{H}=0.372$ ) on five loci, by Oliveira and Charmet (1988) in populations from northwestern Spain $(\mathrm{A}=3.16, \mathrm{H}=0.395)$ on seven loci, by Charmet et al (1993) for 60 perennial ryegrass populations from France and seven polymorphic isozyme loci $(\mathrm{A}=2.75, \mathrm{H}=0.270)$ and Loos (1994) for 60 European populations and cultivars of $L$ perenne and five loci $(\mathrm{A}=2.70, \mathrm{H}=$ 0.308 ). The means of both parameters were higher in these studies than in the work of Hamrick and Godt (1990) because none of the loci studied here were monomorphic.

The mean value $F_{I S}$ of 0.039 is comparable with the values reported by Hayward and McAdam (1977) for $L$ perenne cultivars, Oliveira and Charmet (1988) for L perenne Galician populations, Charmet et al (1993) for French perennial ryegrass populations and Loos (1994) for European populations and cultivars of $L$ perenne $L$. This low value leads to the conclusion that collected populations are nearly panmictic. 
Fig 1. Scatterplot of 28 L perenne populations, based on the Cavalli chord distances calculated from the allelic frequencies for ten allozymes loci. For the populations, the following abbreviations were used: SP, Spain; PO, Portugal; F, France.
CMD-scale of Cavalli chord distance

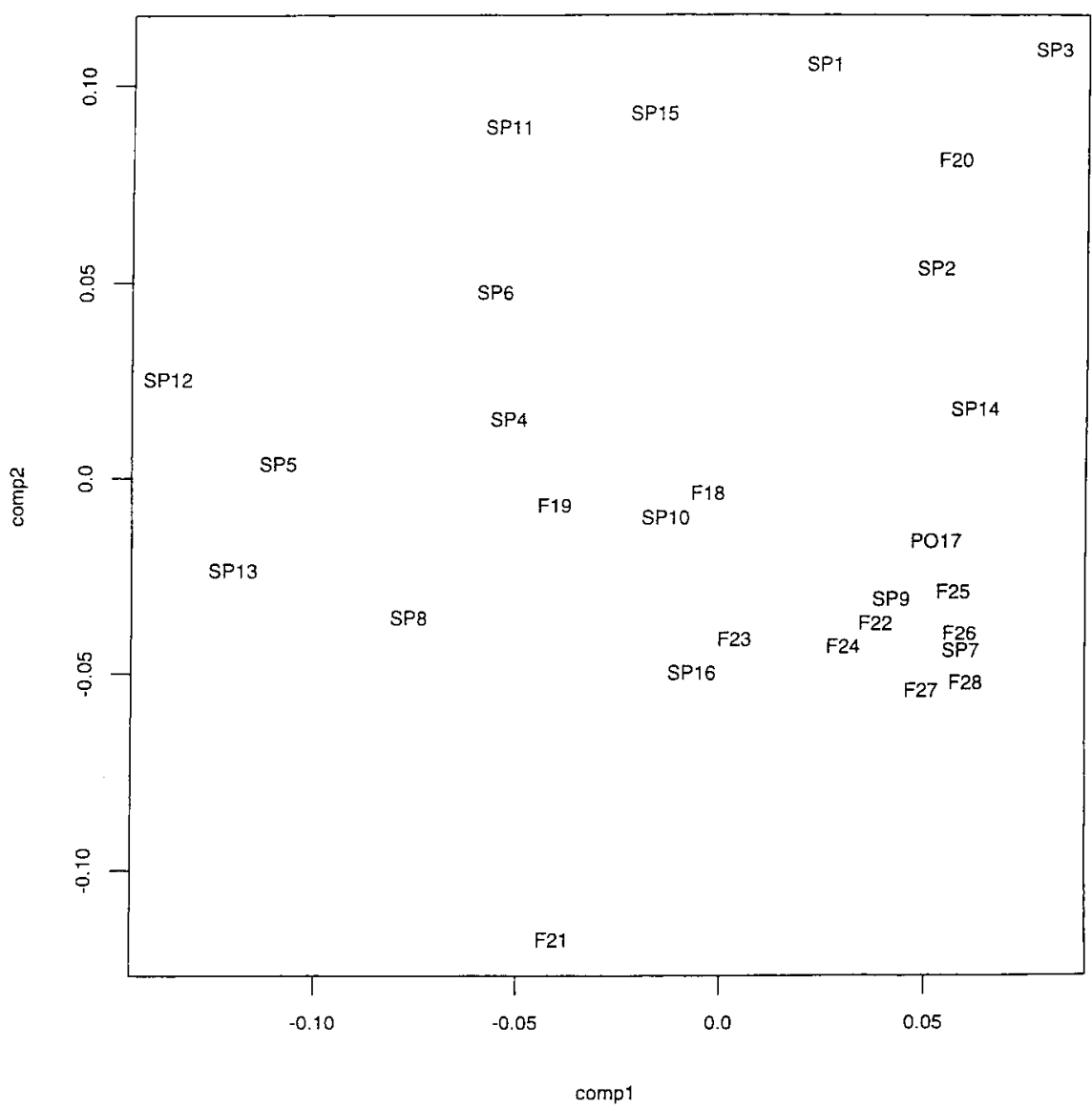

The fact that most of the total gene diversity is accounted for by the within population variation component agrees with Hamrick and Godt (1990). This suggests that sampling few populations for conservation of genetic resources could be sufficient to preserve most of the species isozymic variation. Large effective population size must be used to avoid genetic drift.

Most alleles showed no geographic structuration. As reported by Sokal (1986), such an absence of geographic structure could be explained by near panmixia over the whole geo-

Table IV. Table of deviance explained by logistic regression.

\begin{tabular}{lccc}
\hline Alleles & Altitude & Latitude & Longitude \\
\hline PGI2-20 & $24.06 * *$ & $52.80 * *$ & 1.02 \\
ACP2-20 & $13.85 * *$ & $77.08 * *$ & 0.03 \\
SDK1-30 & $28.15 * *$ & 2.46 & 1.33 \\
\hline
\end{tabular}

$* *$ = significant at 0.001 level. graphic ranges. The panmixia hypothesis is supported by the high estimate of average gene flow among populations. Such a high gene flow among populations might be accounted for by long-distance seed transport by animals, or even pollen transport by wind if we assume very large neighborhood sizes in a continuous population model.

However, some alleles showed clinal patterns of geographic variation, the most clear being that of the ACP2-20 (former ACP2-a) and PGI220 (former PGI2-a), which show a clinal trend from southwest to northwest. There are two evolutionary hypotheses to account for these existing clinal variation in allele frequencies: it could be explained either by selection of different alleles along a geographical or ecological gradient (Endler, 1977), or as a consequence of migration and long-range dispersal along a geographical axis (Wijsmann and Cavalli-Sforza, 1984). Other isozyme surveys reported a south-north cline for different alleles in a collection of French perennial ryegrass populations (Charmet et al, 1993) and in a European collection of ryegrass populations from England to Italy (Loos, 


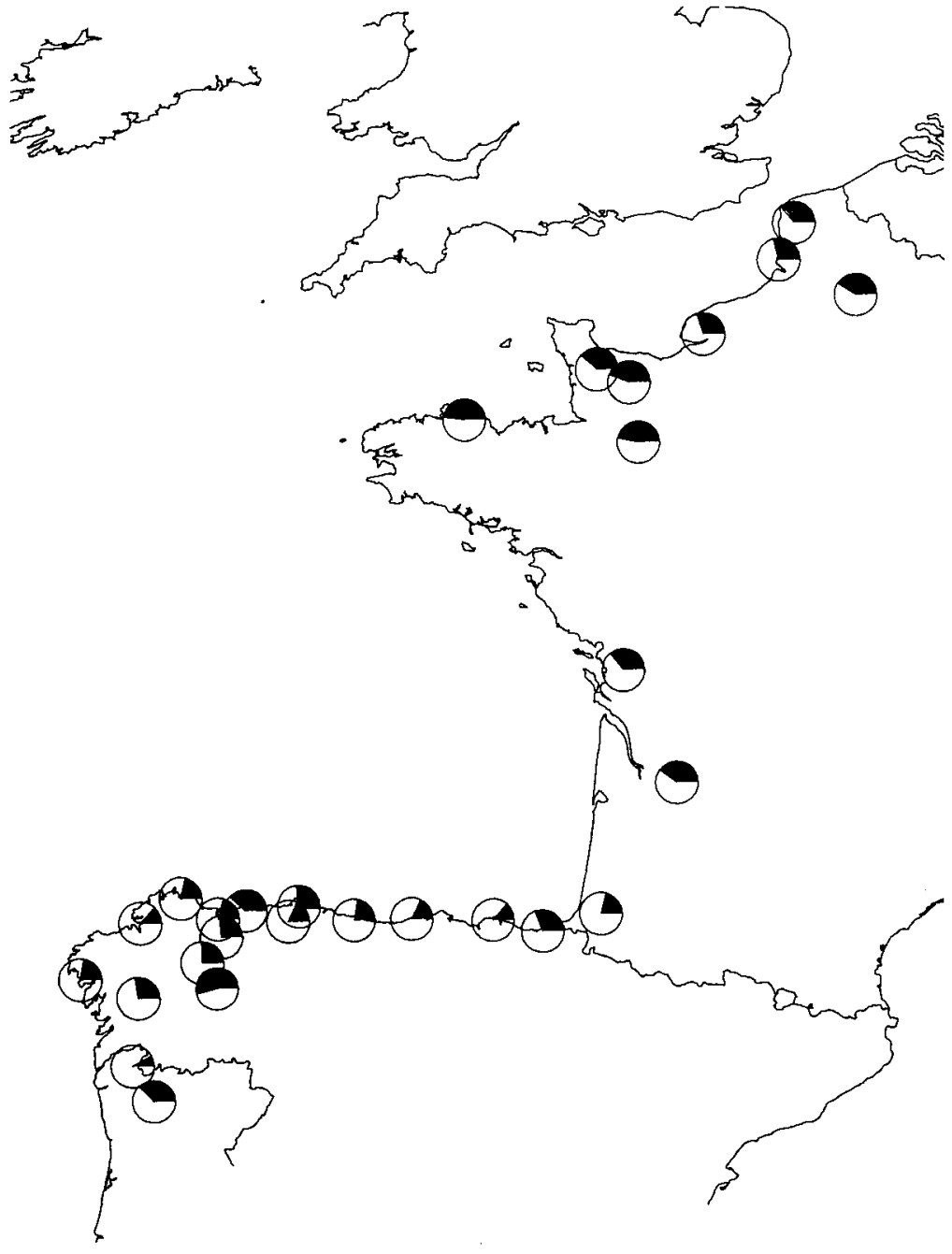

Fig 2. Geographic patterns of variation for PGI2-20 allele in 28 populations of $L$ perenne. Filled sectors are proportional to allele frequency.
1994). These authors seems to prefer the migration hypothesis.

We also observe that the PGI2-20 allele seems to be linked with altitude. This could probably be explained by the selection hypothesis; in that way, Humphreys (1992) observed a consistent association between water soluble carbohydrate content and genotype at the PGI2 locus. This locus is involved in the increase in water soluble carbohydrate content, producing an osmotic effect responsible for a better frost tolerance. In these conditions, it is possible to imagine that altitude of evolution site (and consequently low temperature) interacts with the enzymatic reaction and acts as a selection pressure (Balfourier et al, 1997). As for the relationships between SKD1-30 allele and altitude, if we consider the neutral theory, we can also suppose that this locus is closely linked to a quantitative trait locus, which is selected by altitude.
Thus, some relationships seem to exist between few alleles and geographical data of evolution site, illustrating a geographical structure of the diversity. However, it is difficult to make conclusions about the origin of the structure: for ACP220 and PGI2-20 alleles linked with latitude, the migration or colonization hypothesis appears attractive but, in that case, a similar cline of variation should have been observed for all loci (Barbujani, 1988). In fact, it would be necessary to realize such a study on a larger geographical scale and with more numerous populations, as realized on forest tree species where similar south-north clines have been suggested (Michaud et al, 1994; Leonardi and Menozzi, 1995; Zanetto and Kremer, 1995). All these authors explain such clines as a consequence of colonization since postglacial refugia zones. In this way, to support the selection hypothesis, it would be necessary to sample populations on several distant climatic 
Fig 3. Logistic regression between altitude and SKD130 allele frequency.

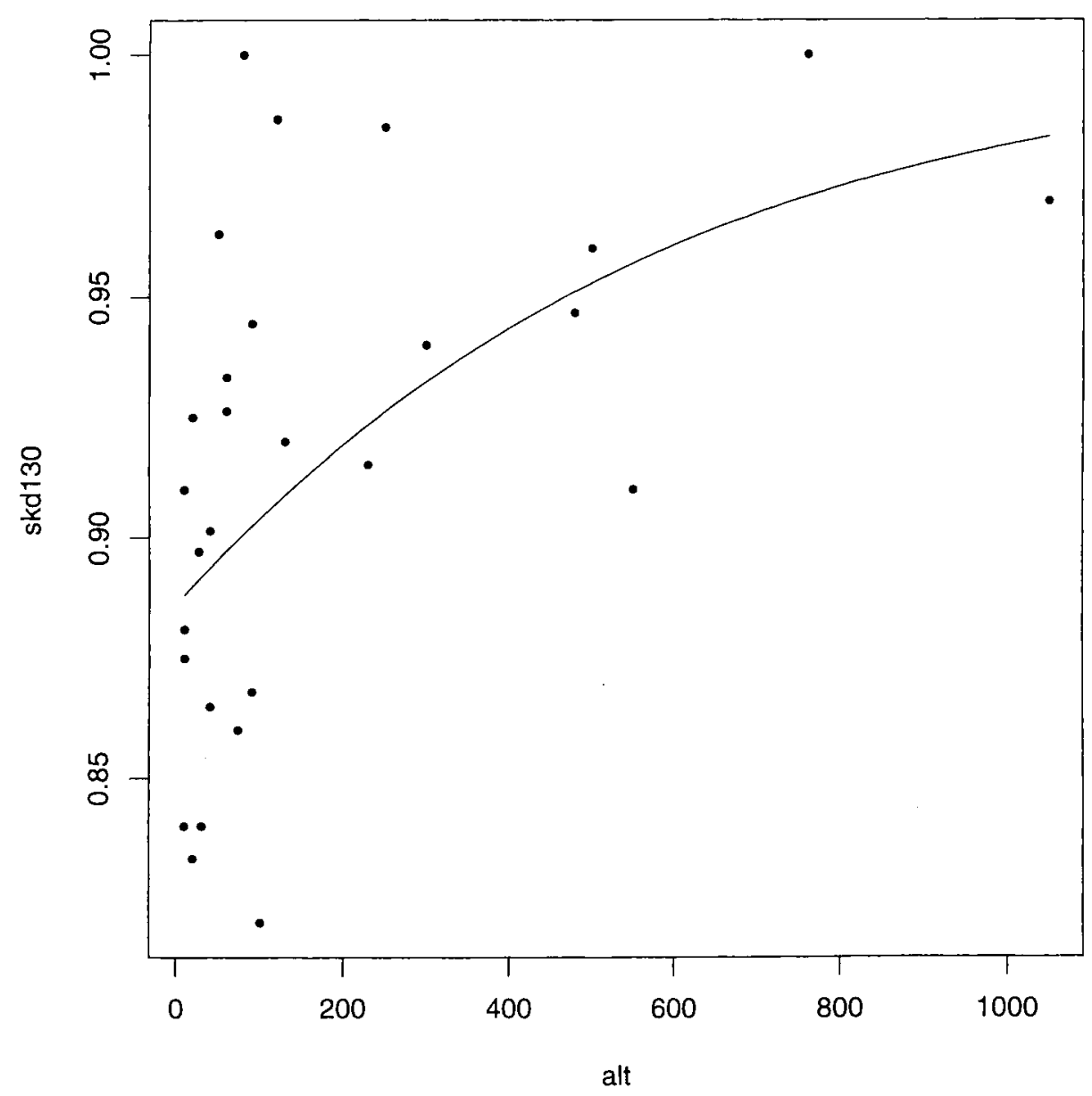

and geographical gradients, as did Lumaret (1984) in Dactylis glomerata L. These studies are in process at the present time and will be presented in a further paper.

\section{REFERENCES}

Arcioni S, Damiani F, Mariotti D, Pezzotti M, Carpinelli G (1988) Enzymatic polymorphism and ecological environment in Italian land race populations of Lolium perenne L. Agric Mediterrana 118, 166-176

Balfourier F, Charmet G (1994) Geographical patterns of isozyme variation in Mediterranean populations of perennial ryegrass. Heredity $72,55-63$

Balfourier F, Oliveira JA, Charmet G, Arbones E (1997) Factorial regression analysis of genotype by environment interaction in ryegrass populations, using both isozyme and climatic data as covariates. Euphytica (in press)

Barbujani G (1988). Detecting and comparing the direction of gene frequency gradients. J Genet 67 , 129-140
Becker RA, Chambers JM, Wilks AR (1988) The new $S$ language. A programming environment for data analysis and graphics. Wadsworth and Brooks/Cole Advanced Books and Software, Pacific Grove California

Brown AHD (1978) Isozymes, plant population genetic structure and genetic conservation. Theor Appl Genet 52, 145-147

Cavalli-Sforza LL, Edwards WF (1967) Phylogenetic analysis: Models and estimation procedures. Evolution 21, 550-570

Charmet G, Balfourier F, Ravel C (1993) Isozyme polymorphism and geographic differentiation in a collection of French perennial ryegrass populations. Genet Res Crop Evol 40, 77-89

Charmet G, Balfourier F (1994) Isozyme variation and species relationships in the genus Lolium $L$ (ryegrasses Graminaceae). Theor Appl Genet 87, 641649

Collett D (1991) Modelling Binary Data. Chapman and Hall, London

Cox DR, Snell EJ (1989) The Analysis of Binary Data, 2 ed. Chapman and Hall, London

Endler JA (1977) Geographic Variation, Speciation and Clines. Princeton University Press, Princeton, NJ 
Greneche M, Lallemand J, Michaud O (1991) Comparison of different enzyme loci as a means of distinguishing ryegrass varieties by electrophoresis. Seed Sci Technol 19, 147-158

Hamrick JL, Godt MJW (1990) Allozyme diversity in plant species. In: Plant Populations Genetics (ADH Brown, MT Clegg, AL Kahler, BS Weir, eds), Breeding Germplasm Resources, Massachusetts Sunderl, 46-63

Hayward MD (1985) Adaptation, differentiation and reproductive systems in Lolium perenne. In: Genetic Differentiation Dispersal in Plants (P Jacquard, G Hein, J Antonovics, eds), NATO-ASI series vol 65, 89-94, Springer-Verlag, Berlin

Hayward MD, McAdam NJ (1977) Isozyme polymorphism as a measure of distinctiveness stability in cultivars of Lolium perenne. Z Pflanzenzucht 79 , 59-68

Hayward MD, Degennars GH, Balfourier F, Eickmeyer F (1995) Isozyme procedures for the characterisation of germplasm exemplified by the collection of Lolium perenne L. Gen Res Crop Evol $42,327-337$

Humphreys MO (1992) Association of agronomic traits with isozyme loci in perennial ryegrass (Lolium perenne L). Euphytica 59, 141-150

Kimura M (1983) The Neutral Theory of Molecular Evolution. Cambridge University Press, Cambridge

Kruskal JB, Wish M (1978) Multidimensional scaling. Sage University papers: Quantitative applications in the social sciences no 07-011, Beverly Hills, Sage

Leonardi S, Menozzi P (1995) Spatial structure of genetic variability in natural stands of Fagus sylvatica $\mathrm{L}$ (beech) in Italy. Heredity 77, 359-368

Loos BP (1994) Allozyme differentiation of European populations cultivars of Lolium perenne $L$ and relation to ecogeographical factors. Euphytica 80, 4957

Lumaret R (1984) The role of polyploidy in the adaptative significance of polymorphism at the Got-1 locus in the Dactylis glomerata complex. Heredity 52, 153-169

Michaud H, Toumi L, Lumaret R, Li TX, Romand F, Di Giusto F (1994) Effect of geographical discontinuity on genetic variation in Quercus ilex (holm oak). Evidence from enzyme polymorphism. Heredity 74, 590-606
Nei M (1977) F-statistics analysis of gene diversity in subdivided populations. Ann Human Genet 41, 225233

Nevo E, Beiles A, Kaplan D, Golenberg EM, OlsvigWhittaker, Naveh Z (1986) Natural selection of allozyme polymorphisms A microsite test revealing ecological genetic differenciation. Evolution 40, 1320

Oliveira JA, Charmet G (1988) Polimorfismo isoenzimatico de seis poblaciones naturales de raigras ingles de Galicia. Pastos 18-19, 69-85

Ostergaard H, Nielsen G, Johansen H (1985) Genetic variation in cultivars of diploid ryegrass Lolium perenne and Lolium multiflorum at five enzyme systems. Theor Appl Genet 69, 409-421

Piñeiro J, Perez M (1992) Mezclas pratenses de la España Húmeda, Ministerio de Agricultura Pesca y Alimentación, Hoja divulgadora Núm 8/92 HD, 1 48

Pollans NO, Allard RW (1985) Inheritance of electrophoretically detectable variants in ryegrass. $J$ Hered 76, 61-62

Rogers JS (1972) Measures of genetic similarity and genetic distance, studies in Genetics. VII University of Texas publication $7213,145-153$

Sokal RR (1986) Spatial analysis and historical processes. In: Data Analysis and Historical Processes (Diday, Escouffier, Lebart, Pages, Shektman and Tomassone, eds), North Holland, Amsterdam, 29-43

Swofford DL, Selander RB (1981) BIOSYS 1 A Fortran program for the comprehensive analysis of electrophoretic data in population genetics systematics. $J$ Hered 72, 281-283

Tyler BF, Chorlton KH, Thomas ID (1984) Characterisation of collected Lolium perenne populations. Rep Welsh Plant Breeding Stn 1983, Aberystwyth UK, 29-32

Wijsmann EM, Cavalli-Sforza LL (1984) Migration and genetic population structure with special reference to humans. Ann Rev Ecol Syst 15, 279-301

Wright S (1965) The interpretation of population structure by F-statistics with special regards to systems of mating. Evolution 19, 395-420

Zanetto A, Kremer A (1995) Geographical structure of gene diversity in Quercus petraea (Matt) Liebl 1. Monolocus patterns of variation. Heredity 75, 506517 